\section{Single lesion as an indicator to monitor the leprosy trend to elimination in hyperendemic areas}

\section{Lesão única como indicador de monitoramento de tendência de eliminação da hanseníase em áreas hiperendêmicas}

\section{Eliane Ignotti' \\ Manuel Bayona ${ }^{2}$ \\ Carolina Alvarez-Garriga ${ }^{2}$ \\ Vera L.G. Andrade ${ }^{3}$ \\ Joaquim G. Valente ${ }^{4}$}

'Departamento de Enfermagem da Universidade Estadual de Mato Grosso (UNEMAT) e Instituto de Saúde Coletiva da Universidade Federal de Mato Grosso (ISC/UFMT)

${ }^{2} \mathrm{~S}$ chool of Public Health, University of Nevada Reno (UNR)

${ }^{3}$ Escola Nacional de Saúde Pública (ENSP/FIOCRUZ)

${ }^{4}$ Escola Nacional de Saúde Pública (ENSP/FIOCRUZ), Instituto de Medicina Social da Universidade do Estado do Rio de Janeiro (IMS/UERJ)

Acknowledgment. We thank Dr. Marcos Virmond for his professional and editorial suggestions. We appreciate the cooperation and assistance of the local level leprosy program in the Municipal Health Department of the city of Palmas, in particular Dr. Neilton Araújo de Souza.

Financial support: this study was supported by the Coordenação de Aperfeiçoamento Pessoal de Nível Superior (CAPES), and University of State of Mato Grosso (UNEMAT).

Correspondência: Eliane Ignotti. Av. República do Líbano 10, Bloco D - 61 - Senhor dos Passos Cuiabá - MT - 78048-135. Fone: 55.65.36314370. E-mail: eignotti@uol.com.br

\section{Resumo}

Introdução: As taxas de detecção e prevalência de hanseníase não são suficientes para mostrar a real magnitude de mudanças nos padrões epidemiológicos da doença. Objetivos. Avaliar a aplicabilidade e utilidade da medida de proporção de casos de hanseníase com lesão única de pele como potencial indicador de avaliação do progresso da eliminação da hanseníase em áreas hiperendêmicas. Metodologia: Estudo retrospectivo baseado na análise de dados secundários de casos novos de hanseníase notificados entre 1997 e 2002 na cidade de Palmas, estado de Tocantins, Brasil. Os registros de pacientes com lesão única foram comparados àqueles registrados com mais de uma lesão. Odds ratio foi utilizado como medida de associação. Resultados: De um total de 1.303 casos novos de hanseníase notificados, 481 (36,9\%) apresentavam lesão única de pele. Verificou-se tendência de incremento na proporção de casos de casos novos diagnosticados com lesão única variando de 20,3\% em 1999 para 49,1\% em 2002 (p < 0,001), simultaneamente à redução do registro de número de casos novos após 1999. Maior proporção de pacientes com lesão única de pele foi verificada em pacientes do sexo feminino, menores de 15 anos, paucibacilares nas formas clínicas tuberculóide e indeterminada, com baciloscopia negativa, com lesões do tipo mácula, sem incapacidades físicas e diagnosticados em unidades básicas de saúde. Conclusões: Os resultados confirmam que a proporção de pacientes com lesão única de pele pode ser utilizada como indicador na avaliação do progresso da eliminação da hanseníase em áreas hiperendêmicas.

Palavras-chave: Hanseníase. Vigilância epidemiológica. Brasil. 
Abstract

Introduction: Prevalence and detection rates of leprosy are not sufficient to show the real magnitude of changes in epidemiological patterns. Objectives: Evaluate the feasibility and usefulness of the proportion of new leprosy patients with a single skin lesion (SSL) as a potential indicator of the elimination of leprosy. Methods: We conducted a retrospective study based on secondary data analyzing newly reported cases of leprosy between 1997 and 2002, in the city of Palmas, Tocantins, Brazil. Patients with a single lesion were compared to remaining patients, and the odds ratio was used as measure of association. Results: Out of the 1,303 new cases of leprosy, 481 (36.9\%) had a SSL. An increasing time-trend was observed in the proportion of new cases detected with a single lesion, which grew from $20.3 \%$ in 1999 to $49.1 \%$ in 2002 (linear trend $\mathrm{p}<.001$ ) while a reduction in the number of new cases was observed simultaneously after 1999. The proportion of patients with a single lesion was higher in women, young age, paucibacillary, tuberculoid and indeterminate clinical forms, residents of urban areas, those with negative baciloscopy, with macular lesions, without physical disabilities, and mainly detected in primary health care units. Conclusions: These findings confirm that the proportion of patients with a SSL can be used as a sensitive and feasible indicator to assess the progress of the elimination of leprosy in hyperendemic areas.

Keywords: Leprosy. Epidemiologic surveillance. Brazil.

\section{Introduction}

The main indicator for monitoring the magnitude of leprosy transmission around the world has been the prevalence rate. It has also been used as a reference in the process of elimination of the disease. Andrade et al. (1998) ${ }^{1}$ showed how prevalence rates could be influenced by operational factors of the elimination program more than by the epidemiological patterns of the disease. Lechat, in 1999, ${ }^{2}$ evaluated the usefulness of prevalence rates, especially in the generalization of results to large geographical regions.

In Brazil, in spite of the significant reduction of prevalence rates from 18.2 per 10,000 in 1990 to 4.5 per 10,000 in 2002 , a considerable epidemiological variation could be noticed between different regions. Areas that had already achieved the condition of elimination many years ago, areas close to achieving it, and other areas such as the states of the Amazon region that still have prevalence rates higher than 20 cases per 10,000 inhabitants could be differentiated ${ }^{3}$. The state of Tocantins presented a 9.17 detection rate and 8.67 prevalence rate in $2002^{4}$.

Another important epidemiologic indicator is the detection rate that is being used to assess the magnitude and secular trend of the disease ${ }^{5}$. Both prevalence and detection rates, due to their lack of sensitivity, show small secular variations throughout long historical series whenever they are used in hyperendemic areas, making it difficult to evaluate the progress of elimination efforts.

Some epidemiologic studies of secular trends of leprosy were carried out using alternative indicators such as level of disability at the time of diagnosis, proportion of multibacillary cases, and proportion of cases younger than 15 years of age a $^{1,5-8}$. However, in some areas, not even the combination of these variables was sensitive enough to reflect variations in the magnitude of the disease.

The proportion of single lesion patients 
has been used as an indicator of the effectiveness of the active search of new cases in Leprosy Elimination Campaigns (LECs), especially in India ${ }^{9-11}$. In Brazil, the number of lesions at the time of diagnosis has been part of the case-reporting data form since year 2000. However, the Ministry of Health has not used this information yet. The purpose of this study is to assess the use of the proportion of patients with a single skin lesion among new cases of leprosy as a potential indicator of the elimination efforts in hyperendemic areas such as the city of Palmas (state of Tocantins, Amazon region, North of Brazil).

\section{Methods}

A retrospective study based on secondary data analyzing newly reported cases of leprosy between 1997 and 2002, in the city of Palmas, Tocantins, Brazil, was conducted with the purpose of assessing the proportion of patients with a Single-Skin Lesion (SSL), among all new cases of leprosy reported in Palmas. We also wanted to find out whether this proportion could be used to evaluate progress toward the elimination of leprosy in Brazil. The proportion of SSL patients was calculated and studied through the analysis of time trends, because the proportion of SSL patients was considered a sensitive indicator to evaluate elimination efforts and epidemiological patterns of leprosy elimination, and that occurs earlier than other traditional indicators. Then, larger proportions of single-skin-lesion patients should be found among cases with characteristics such as, for instance, young age, female gender, no physical disability, paucibacillary, indeterminate or tuberculoid clinical form, with a negative baciloscopy, with macular lesions, residents of urban areas, and mainly detected in primary healthcare units. Data was obtained from two different sources: the National System of Reportable Diseases (SINAN), and from medical charts of every leprosy case reported from all healthcare providers in Palmas during the study period. Variables included in the Standard Leprosy Reporting Form were used for the study. In order to revise and correct gaps and errors, the data obtained from the Brazilian Ministry of Health was revised by medical record linkage (patient's name, mother's name and date of birth) in which eight cases not previously reported were found and added to the study.

\section{Description of study site and healthcare organization}

The city of Palmas is a new city that was built to be the capital of a new state in Brazil, in 1989. Unlike other Brazilian cities, the city of Palmas was planned and built within an organized territorial space, with $98 \%$ of the population living in urban areas, with water supply, sewage and garbage collecting services for the whole urban population. The study was conducted in Palmas, due to two major issues. First, in 1998, the Task Force for the Acceleration of Leprosy Elimination started its activities there $^{12}$. The Task Force's work was based on professional training, information to the population, integration of treatment in all primary health centers, increasing the access to leprosy services. The second reason is that Palmas has been a reference city, with Primary Health Centers with family physicians serving $100 \%$ of the urban population, since 2000 .

\section{Case Definition}

Cases were leprosy patients recorded or reported with a single lesion at the time of diagnosis that were compared to leprosy patients with more than one lesion. According to the World Health Organization, the definition of single lesion refers to patients who only have one skin lesion with hypo or hyper pigmentation, with loss of sensation, but without peripheral nerve thickness $^{13}$. In this study, nerve thickness was not included into the definition because this piece of information was not recorded before 2001 . 


\section{Variables under Study}

Study variables included: year of diagnosis, operational classification (pauci and multibacillary); clinical form (Madrid's classification, 1953), gender, age, area of residency (urban or rural), way of detection (referral, walk-in, or contact investigation), presence or absence of physical disability; type of skin lesion (macula or other leprosy compatible lesion that includes nodule and papule), negative or positive baciloscopy, and health care facility reporting the case, including primary healthcare center, healthcare center, polyclinic, and hospitalbased outpatient clinic. Due to important healthcare similarities, primary health care center, health care center, and hospitalbased outpatient family clinic were combined for analysis. Polyclinic and hospitalbased outpatient clinics with dermatologists were also combined.

\section{Data Analysis}

Frequency distributions were used to assess the integrity of data, correct errors, evaluate the feasibility of data analysis, and recode the categories of selected variables as needed. To evaluate the usefulness of the proportion of single lesions as an indicator to monitor leprosy elimination efforts, individuals with SSL were compared to individuals with two or more lesions regarding selected variables. Age was analyzed first as a continuous variable. The mean age difference between individuals with and without single lesions was used. The T-test was used to assess the statistical significance of the mean difference. The $95 \%$ percent confidence interval, using the normal approximation, was used to assess the precision of the mean difference $^{13}$. For further analysis, age was classified using percentiles as cut-off points. The proportion of cases with single lesions among categorical variables was evaluated by using cross-tabulation. The crude Odds Ratio (OR) was used as a measure of association. The 95\% confidence interval for the OR was calculated by using the exact method $^{14,15}$. The two-tailed Fisher's exact test was used to evaluate the statistical significance of the OR. The time trend was evaluated by using chi square tests for linear trend and slope ${ }^{16}$. To explore interaction and confounding effects, the stratified Mantel-Haenszel analysis was used. A variable was considered to be a confounder if there was a relative difference of $15 \%$ or more between the crude and the adjusted $\mathrm{OR}^{15}$. Interaction or effect modification was to be considered whenever the Odds Ratio between strata were remarkably different and/or if the Breslow-Day test for homogeneity of the Odds Ratios was at least of borderline statistical significance ${ }^{17}$. However, no important or statistically significant interactions were found in this study.

Logistic regression analysis adjusted OR was used to assess the differences between individuals with and without SSL adjusting for all confounders simultaneously ${ }^{15,18,20}$. Continuous variables were classified for the analysis to assess strength of association and dose-response relationship. However, when other variables were analyzed, continuous variables included in the model were not classified to prevent residual confounding. SPSS and Epi Info statistical packages were used for the analysis ${ }^{20}$. Figures were prepared using Stats Direct statistical package ${ }^{22}$.

\section{RESULTS}

By examining the standard epidemiological indicators currently used (table 1): the prevalence rate increased until 1999 and steadily decreased until 2001. From 2001 to 2002 the prevalence rate decreased significantly. Detection rates increased until 1999 and decreased thereafter. Nevertheless, it is not known if this reduction is due to a real decrease in the number of cases or a decrease in detection capacity. Lastly, new cases and detection rates in the population younger than 15 years of age fluctuated throughout the time series not reflecting any real trend. 
During the study period from 1997 to 2002 in Palmas, case detection and leprosy treatment improved, because before 2000, diagnoses were made only in two specialized clinics; after that period, every primary health center was able to diagnose and treat leprosy patients. Consequently, the number of new cases increased until 1999 and decreased thereafter. The case series studied included 481 (36.9\%) SSL cases among 1,303 new cases of leprosy. An important and statistically significant increasing time trend in the proportion of cases with SSL, from 20.3 to $49.1 \%$ can be observed in Figure $1\left(\chi^{2}=43.9, \mathrm{p}<0.001\right)$ while the number of new cases increased only until 1999.

Table 2 shows that females are $40 \%$ more likely to have a single skin lesion (SSL) as compared to males $\left[\mathrm{OR}_{\text {adj }}=0.60\right.$; $95 \%$ C.I. $(0.47-0.77)]$. The proportion of new cases with SSL decreased with increasing age $(p=0.007)$. Using the youngest age group ( 0 - 21 years of age) as a reference, a reduction in the likelihood of having a single skin lesion can be seen for each older age group, in comparison to multiple skin lesions. After adjusting by gender, age, type of health center, and using year 1997 as a reference, an increasing trend can be seen with statistically significant results ranging from 1.7 to 4.3 times more likely to have a single skin lesion from 1998 to 2002.

The area of residence, after adjusting by gender, age and year of diagnosis, showed that patients from the urban area were six times more likely to have a single skin lesion than those from the rural area $\left[O R_{a d j}=6.48 ; 95 \%\right.$ C.I. $\left.(1.47-28.59)\right]$. After adjusting for year of diagnosis, cases reported from primary health care centers were $31 \%$ more likely to have a single skin lesion than those from polyclinics [OR= 1.31 ; $95 \%$ C.I. (0.98 - 1.76)]. No statistically significant association was found in the way cases were detected in this study.

Table 3 shows that paucibacillary cases were much more likely to have a single lesion as compared to multibacillary $\left[\mathrm{OR}_{\mathrm{adj}}=\right.$ 12.09; 95\% C.I. (8.15 - 17.93)]. Cases with an indeterminate form of leprosy were more likely to have single skin lesions than the rest of the clinical forms. Using the indeterminate form as a reference, tuberculoid cases were $17 \%$ (not statistically significant), lepromatosus 87\%, and dimorphs $93 \%$ less likely to have single skin lesions. The difference between the number of lepromatosus and dimorphs cases in comparison with MB cases is justified by the need to identify the operational classification of each patient, but not the clinical form.

Table 1 - Estimated population, annual distribution of the prevalence and detection rates, and detection rates among individuals less than 15 years old, Palmas - Tocantins State, Brazil (1997 - 2002)*.

Tabela 1 - População estimada, distribuição das taxas de prevalência e detecção anual de hanseníase e taxa de detecção entre menores 15 anos de idade, Palmas - Tocantins, Brasil (1997 - 2002)*.

\begin{tabular}{lccccc}
\hline Year & $\begin{array}{c}\text { Estimated } \\
\text { Population }\end{array}$ & $\begin{array}{c}\text { Prevalence } \\
\text { Rate }\end{array}$ & $\begin{array}{c}\text { Detection } \\
\text { Rate }\end{array}$ & $\begin{array}{c}\text { Population } \\
<15 \text { years old }\end{array}$ & $\begin{array}{c}\text { Detection Rate } \\
<15 \text { years }\end{array}$ \\
\hline 1997 & 99.446 & 16.8 & 15.4 & 35,305 & 5.1 \\
1998 & 110.667 & 35.3 & 19.8 & 39,289 & 6.9 \\
1999 & 121.919 & 54.1 & 23.7 & 43,283 & 4.4 \\
2000 & 137.355 & 51.5 & 17.4 & 45,187 & 4.1 \\
2001 & 150.882 & 50.1 & 15.2 & 49,636 & 5.1 \\
2002 & 161.138 & 30.9 & 10.7 & 53,012 & 3.1 \\
\hline
\end{tabular}

Source: SINAN - Leprosy. Municipal Department of Health, Palmas - Tocantins, Brazil (2003).

Fonte: SINAN - Hanseníase. Secretaria Municipal de Saúde, Palmas - Tocantins, Brasil (2003).

* Rates calculated by 10,000 habitants $/{ }^{*}$ Taxas calculadas por 10.000 habitantes 


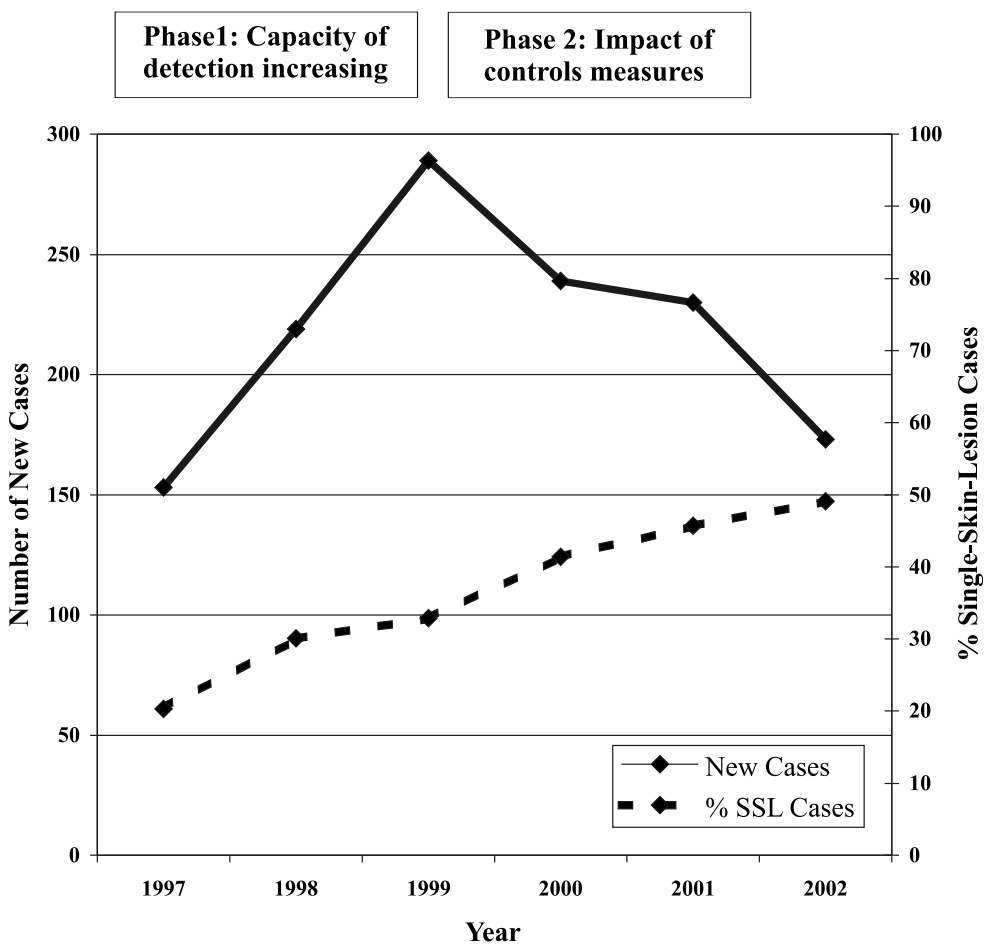

Source: SINAN - Leprosy. Municipal Department of Health, Palmas- Tocantins, Brazil (2003).

Fonte: SINAN - Hanseníase. Secretaria Municipal de Saúde, Palmas - Tocantins, Brasil (2003)

Figure 1 - New cases of leprosy and proportion of single-skin-lesion cases by reporting year. Palmas - Tocantins State, Brazil (1997 - 2002).

Figura 1 - Casos novos de hanseníase e proporção de casos com lesão única de pele por ano de notificação. Palmas - Tocantins, Brasil (1997 - 2002).

The probability of having a single skin lesion among those with negative baciloscopy was almost twice greater than those with positive baciloscopy $\left[\mathrm{OR}_{\mathrm{adj}}=\right.$ 1.90; 95\% C.I.(1.15 - 3. 08)]. Cases with a single skin lesion were about three times more likely to have a macula than other leprosy skin lesion $\left[\mathrm{OR}_{\mathrm{adj}}=2.94 ; 95 \%\right.$ C.I. (1.47 - 5.89)]. No statistically significant association was found in the way cases were detected in this study.

\section{Discussion}

The present study was carried out to assess the proportion of cases with a single skin lesion (SSL) as an indicator of the trend of leprosy elimination in hyperendemic areas. Usual indicators, like prevalence or detection rate, are not sensitive enough; moreover, they are not affected by the endemic process itself, but are also influenced by the operational capacity of the elimination program.

Reporting the number of skin lesions in new cases of leprosy began with the introduction of large-scale multi-drug therapy (MDT) in Brazil, in 1991. The number of skin lesions reported was connected to the ROM protocol, used only in reference units with dermatologists or leprologists ${ }^{22}$. There is evidence ${ }^{23-27}$ showing the potential value of using a single dose to treat SSL leprosy cases, although this is not used in Brazil. A case of leprosy with a single skin lesion indicates the presence of early manifestations of the disease $^{13,28}$. Lechat $(1996)^{7}$ stated that early detection eliminates the emergence of cases in the future.

Current epidemiological indicators do not allow identifying changes in the mag- 
Table 2 - Distribution of new cases of leprosy with and without single skin lesion, by gender, age, year of diagnosis, place of residence and type of health center. Palmas - Tocantins, Brazil (1997 to 2002).

Tabela 2 - Distribuição de casos novos de hanseníase com e sem lesão única da pele, por sexo, idade, ano de diagnóstico, local de residência e tipo de serviço de saúde. Palmas - Tocantins, Brasil (1997 - 2002)*.

\begin{tabular}{|c|c|c|c|c|c|}
\hline Variables & Single Skin Lesion & No Single Lesion & OR 95\% & OR adjustado $95 \%$ & $p$-value \\
\hline \multicolumn{6}{|l|}{ Gender $^{\mathrm{a}}$} \\
\hline Male & 227 (31.2\%) & $501(68.8 \%)$ & $0.57(0.46-0.72)$ & $0.60(0.47-0.77)$ & $<0.001$ \\
\hline Female & $254(44.2 \%)$ & $321(55.8 \%)$ & 1.0 & 1.0 & \\
\hline \multicolumn{6}{|l|}{ Age in years ${ }^{b}$} \\
\hline 0 to 21 & $110(36.1 \%)$ & 195 (63.9\%) & 1.0 & 1.0 & \\
\hline 22 to 31 & 114 (39.9\%) & $172(60.1 \%)$ & $1.17(0.84-1.64)$ & $1.21(0.87-1.70)$ & 0.257 \\
\hline 32 to 45 & 93 (32.1\%) & 197 (67.9\%) & $0.83(0.59-1.17)$ & $0.85(0.61-1.20)$ & 0.360 \\
\hline 46 and more & $77(27.3 \%)$ & $205(72.7 \%)$ & $0.66(0.47-0.95)$ & $0.71(0.50-1.00)$ & 0.057 \\
\hline \multicolumn{6}{|l|}{ Year of diagnosis ${ }^{c}$} \\
\hline 1997 & $31(20.3)$ & $122(79.7)$ & 1.0 & 1.0 & \\
\hline 1998 & $66(30.1)$ & $153(69.9)$ & $1.67(1.04-2.77)$ & $1.50(0.88-2.58)$ & 0.138 \\
\hline 1999 & $95(32.9)$ & $194(67.1)$ & $1.93(1.21-3.10)$ & $1.71(1.01-2.87)$ & 0.044 \\
\hline 2000 & $99(41.4)$ & $140(58.6)$ & $2.78(1.74-4.46)$ & $2.70(1.60-4.57)$ & $<0.001$ \\
\hline 2001 & $105(45.7)$ & $125(54.3)$ & $3.31(2.10-5.30)$ & $3.51(2.08-5.92)$ & $<0.001$ \\
\hline 2002 & $85(49.1)$ & $88(50.9)$ & $3.80(2.32-6.23)$ & $4.27(2.48-7.37)$ & $<0.001$ \\
\hline \multicolumn{6}{|l|}{ Place of residence ${ }^{d}$} \\
\hline Urban & $391(35)$ & $726(65)$ & $7.27(1.72-30.73)$ & $6.48(1.47-28.59)$ & 0.014 \\
\hline Rural & $2(6.9)$ & $27(93.1)$ & & & \\
\hline \multicolumn{6}{|l|}{ Type of health center ${ }^{\mathrm{e}}$} \\
\hline Primary h. care center & $158(45.3)$ & $191(54.7)$ & $1.60(1.25-2.06)$ & $1.31(0.98-1.76)$ & 0.066 \\
\hline Policlinic & $323(34.1)$ & $625(65.9)$ & 1.0 & 1.0 & \\
\hline
\end{tabular}

Source: SINAN - Leprosy. Municipal Department of Health, Palmas - Tocantins, Brazil (2003).

Fonte: SINAN - Hanseníase. Secretaria Municipal de Saúde, Palmas - Tocantins, Brasil (2003).

a adjusted by age / ajustado por idade

b adjusted by gender / ajustado por sexo

c adjusted by age, gender and type of health center / ajustado por idade, sexo e tipo de serviço de saúde

$\mathrm{d}$ adjusted by age, gender, year of diagnosis and area of residence / ajustado por idade, sexo, ano de diagnóstico e local de residência

e adjusted by year of diagnosis / ajustado por ano de diagnóstico

nitude of the disease. We were not sure if the change was due to the magnitude of the disease, or to detection capability. We could only state that Palmas, located in the Amazon region, was a hyperendemic municipality with intense transmission of leprosy, considering prevalence and detection rates.

Cases reported by Primary Health Care Centers were more likely to have a single lesion, even after adjusting for the year of detection. Those Centers are at the frontline, therefore detecting new cases earlier. The other health care units deal with referrals. This illustrates the importance of leprosy elimination program decentralization in primary health care centers. According to the literature, its impact im- proved early detection, including a smaller probability to develop adverse reactions to treatment and lower risk of physical disabilities $^{5,13,29}$, and this in turn reduces the need for more sophisticated specialized services that have accessibility problems.

Females were more likely to have a SSL as compared to males. This association remained important after adjusting for age and year of diagnosis. However, females come more often to health care services as they are more careful in taking care of their health $^{30-32}$. Therefore, leprosy among females would be expected to be detected earlier, regardless of age and year of diagnosis. In Palmas, incidence rates for males and females did not show important differences ${ }^{3}$. Ponnighaus et al. ${ }^{33}$ showed that 
Table 3 - Distribution of new cases of leprosy, by operational classification, clinical form, bacilloscopy, type of skin lesion, physical disability and way of detection. Palmas - Tocantins, Brazil (1997 a 2002).

Tabela 3 - Distribuição de casos novos de hanseníase, por classificação operacional, apresentação clínica, baciloscopia, tipo de lesão cutânea, incapacidade física e modo de detecção. Palmas - Tocantins, Brasil (1997 - 2002)*.

\begin{tabular}{|c|c|c|c|c|c|}
\hline Variables & Single Skin Lesion & No Single Lesion & OR 95\% & Adjusted OR 95\% & $\mathrm{p}$-value \\
\hline \multicolumn{6}{|l|}{ Operational Classification ${ }^{a}$} \\
\hline Paucibacillary & $437(54.2)$ & $369(45.8)$ & \multicolumn{2}{|c|}{$12.19(8.69-17.11) 12.09(8.15-17.93)$} & $<0.001$ \\
\hline Multibacillary & $44(8.9)$ & $453(91.1)$ & & & \\
\hline \multicolumn{6}{|l|}{ Clinical form ${ }^{b}$} \\
\hline Indeterminate & $177(51.0)$ & $170(49.0)$ & 1.0 & 1.0 & \\
\hline Tuberculoid & $171(42.8)$ & $229(57.3)$ & $0.72(0.53-0.97)$ & $0.83(0.61-1.13)$ & 0.239 \\
\hline Dimorphus & $20(7.4)$ & $250(92.6)$ & $0.08(0.05-0.13)$ & $0.07(0.04-0.12)$ & $<0.001$ \\
\hline Lepromatous & $16(13.3)$ & $104(86.7)$ & $0.15(0.08-0.26)$ & $0.13(0.07-0.24)$ & $<0.001$ \\
\hline \multicolumn{6}{|l|}{ Baciloscopy ${ }^{b}$} \\
\hline Negative & $80(32.5)$ & $122(80.2)$ & $2.03(1.24-3.29)$ & $1.90(1.15-3.08)$ & 0.012 \\
\hline Positive & $29(6.9)$ & $166(67.5)$ & 1.0 & 1.0 & \\
\hline \multicolumn{6}{|l|}{ Type of skin Lesion ${ }^{a}$} \\
\hline Macula & 341 (63.6) & $195(36.4)$ & $3.09(1.66-5.74)$ & $2.94(1.47-5.89)$ & 0.002 \\
\hline Other & $17(36.2)$ & $30(63.8)$ & 1.0 & 1.0 & \\
\hline \multicolumn{6}{|l|}{ Phisical disabilities ${ }^{c}$} \\
\hline No & $382(36.1)$ & 677 (63.9) & $1.50(0.93-2.45)$ & $1.34(0.82-2.21)$ & 0.248 \\
\hline Yes & $27(27.3)$ & $72(72.7)$ & 1.0 & 1.0 & \\
\hline \multicolumn{6}{|l|}{ Way of detection ${ }^{d}$} \\
\hline Referral & $103(37.2)$ & $174(62.8)$ & 1.0 & 1.0 & \\
\hline Walk - in & $244(34.1)$ & $471(65.9)$ & $0.87(0.66-1.17)$ & $1.02(0.75-1.38)$ & 0.921 \\
\hline Contact investigation & $35(29.4)$ & $84(70.6)$ & $0.70(0.44-1.12)$ & $0.90(0.55-1.48)$ & 0.686 \\
\hline
\end{tabular}

Source: SINAN - Leprosy Municipal Department of Health, Palmas - Tocantins, Brazil (2003).

Fonte: SINAN - Hanseníase. Secretaria Municipal de Saúde, Palmas - Tocantins, Brasil (2003).

a. adjusted by age, gender, year of diagnosis and area of residence / ajustado por idade, sexo, ano de diagnóstico e local de residência

b. adjusted by age, gender and type of health center / ajustado por idade, sexo e tipo de serviço de saúde

c. adjusted by age, gender, year of diagnosis and operational classification / ajustado por idade, sexo, ano de diagnóstico e classificação operacional

d. adjusted by age, gender, year of diagnosis and type of health center / ajustado por idade, sexo, ano de diagnóstico e tipo de serviço de saúde

skin lesions in females are more frequently found on the face and arms as compared to males. These differences in lesion location facilitate the identification of early leprosy in women. Therefore, major efforts should be made to detect leprosy earlier in males.

Age was classified in different ways by using percentiles. The clinically important cut-off point of 15 years of age did not appear to be significant for SSL. Age was finally classified by quartiles $(0-21 ; 22-31 ; 32-$ $45 ; 46+)$. The second age group, from 22 to 31 years, showed a small, non-statistically significant rise in the proportion of SSL as compared to the youngest age group from 0 to 21 years. Consequently, in Palmas, the probability of young adults, children and teenagers to be detected early may not be different. Older age groups showed smaller proportions and a statistically significant lower probability trend of having a higher proportion of SSL as compared to the youngest age group.

These results could be expected if the proportion of SSL is, in fact, an indicator for early detection ${ }^{6}$. Several secular trends in different countries, during the leprosy elimination period, have suggested that disease transmission occurs in young age and clinical manifestations appear in adulthood. This may explain why, in the present study, there was not an important difference regarding the proportion of SSL in the two younger age groups, and why the two older age groups had less likelihood of having SSL.

The number of skin lesions is used as 
the most important criteria to classify patients as paucibacillary or multibacillary ${ }^{22}$. Therefore, an obvious association of the SSL and paucibacillary categories should be found and does not necessarily mean that SSL is a predictor of paucibacillary category. Otherwise, the quality of the data would be questionable.

Tuberculoid and indeterminate forms are known to have a higher proportion of patients with $\mathrm{SSL}^{34,35}$. This relationship was also found in the present study. Indeterminate cases were used as a reference group. After adjustment, only a small difference was found between tuberculoid and indeterminate cases regarding the proportion of SSL. Tuberculoid cases are common in hyperendemic areas and the presence of a high proportion of SSL among them is suggestive in most cases of early detection. In contrast, SSL was much more frequent in indeterminate cases as compared to lepromatous or dimorphus. According to the literature, macular lesions are more frequently found in the early stages of the disease $\mathrm{e}^{35}$. In the present study, a larger proportion of SSL was found to be macular.

Bacilloscopy was only carried out in 397 (30.5\%) cases. However, a strong and statistically significant association was found between a negative bacilloscopy and SSL after adjusting for type of health care center, age and gender. This indicates that SSL is more likely to be associated with cases that can hardly transmit the infection.

MDT was introduced in Brazil in 1991, but decentralization of care to leprosy patients has occurred gradually since then and in a more intense way after 1999. Palmas is considered an example municipality in care decentralization to primary Healthcare Centers, with healthcare professionals of general non-specialized backgrounds. The city of Palmas is a new city that was built to be the capital of the state. New immigrants accounted for a significant part of the growing city population, while rural areas have remained practically unchanged. Rural areas around the city of
Palmas have less accessibility to healthcare services and case detection may not happen as early as in the urban area. This may explain why urban cases were more than six times as likely to have SSL when compared to rural patients.

No category of type of case detection was found with a higher proportion of SSL. This lack of association may be due to several reasons stemming from a program that has been very active. First, the program increased its professional healthcare staff, thus increasing the number of early referrals. Second, educational campaigns using mass media, including TV programs, theatre groups, posters, and fliers, have been conducted since 1998, increasing walk-in case detection rates and subsequently the proportion of SSL among all leprosy cases. Besides increase in detection rates in Palmas, healthcare services did not value indices-cases of leprosy, as a probable source of infection ${ }^{36,37}$, and new case detection has been at random ${ }^{38}$.

It was not possible to analyze neural thickness beyond physical disability in this study because the database does not have this information available. On the other hand, the analysis between physical disability and SSL adjusted by operational classification was not significant, probably as a result of the change of the epidemiological pattern of leprosy patients over past years $^{12}$. Katoch et $\mathrm{al}^{28}$ showed improvement in the therapy to PB patients with SSL in comparison with $\mathrm{PB}$ with more than one lesion using multidrugtherapy. They suggest that the probability of the risk to develop physical disability, during and after the treatment, could be small in this group.

After the Pan-American Organization (PAHO) Independent Evaluation of the Brazilian National Program in the Leprosy Control and Elimination in 1994, the Ministry of Health concluded that: "Brazil was a country of high prevalence, with an expansion trend of leprosy". The increase in magnitude of crude rates of leprosy detection was a consequence of the increase in transmission ${ }^{39}$. PAHO (2003) ${ }^{40}$ found that 
the changing epidemiological characteristics in the previous decades in Brazil made the evaluation of transmission trends extremely difficult. These changes include an increase in the proportion of patients diagnosed with fewer lesions, a variation in the proportion of multibacillary cases and a decrease of cases with irreversible disabilities.

In 2003, after the Leprosy Elimination Monitoring (LEM), assessment in Brazil reported a difference in the prevalence rate with less then 1.19 cases per 10,000 inhabitants, and an excess of the 27,340 cases when results were compared to the records of the Brazilian Ministry of Health. The proportion of cases detected with SSL in the country was $19 \%$, and in some states like Tocantins this proportion was as high as $25 \%$. However, the proportion of SSL was not considered an indicator of the improvement in the capacity of early detection of healthcare services, but that could suggest that in some areas there is an increase of detecting false positives ${ }^{41}$. In this study, the evaluation of the proportion of reported SSL cases as an indicator of early detection and thus the improvement in detection capacity is based on the reporting by the Brazilian Ministry of Health as it is. No consideration was made of the few potential false positives that may exist. This is because it would be expensive and timeconsuming to validate the diagnosis to assess this indicator more accurately. In spite of this potential problem, the associations found in this study are in concordance with the bibliography.

The proportion of cases with SSL as reported by the Brazilian Ministry of Health was found to be higher among women, young age, paucibacillary, tuberculoid and indeterminate clinical forms, residents of urban areas, those with negative baciloscopy, with macular lesions, without physical disabilities, and mainly detected in primary healthcare units. These findings indicate that the proportion of patients with SSL can be used as a sensitive and feasible indicator to evaluate the progress of leprosy elimination in hyperendemic areas. The results of this study demonstrate the potential benefits of using this indicator and it is hoped that health services in hyperendemic areas will consider evaluating its use.

\section{References}

1. Andrade V, Sabroza PC, Albuquerque MFM, Motta CP. Monitoring the Elimination of Leprosy in Brazil. Int J Lepr Other Mycobact Dis 1998; 66 (4): 457-63.

2. Lechat MF. Rationale for the Preventive Treatment of Leprosy. Int J Lepr Other Mycobact Dis 1999; 67(4): S63S66.

3. MS. Ministério da Saúde. DATASUS. www.datasus.gov.br. Consulted in December 14, 2003.

4. RIPSA. Rede Interagencial de Informações para a Saúde. Indicadores e Dados Básicos - Brasil - 2006. http:/ / tabnet.datasus.gov.br/cgi/idb2006/matriz.htm\#morb.

5. Lechat MF, Vanderveken, Declercq, Mission CB. Analysis of trend in the occurrence of leprosy. Weekly Health Statistics Quarterly 1986; 39: 129-137.

6. Irgens LM, Skjjarven R. Secular trend in age at onset, sex ratio, and type index in leprosy observed during declining incidence rates. Am J Epidemiol 1985; 122(4): 695-705.
7. Lechat MF. Predicting Trend. Int J Lepr Other Mycobact Dis 1996; 64(4); S38-S43.

8. Groenen G. Trends in prevalence and case finding in the ALERT leprosy control Programme, 1979 - 1999. Lepr Rev 2002; 73: 29-40.

9. Mandal MG, Pal D, Majumdar V, Biswas S, Saha B. Recent trends in leprosy in a large district of West Bengal, India, revealed by a modified leprosy elimination campaign. Lepr Rev 2000; 71(1): 71-6.

10. Bhatki WS, Singh MG. Modified leprosy elimination campaign in Mumbai (Bombay), India-a report. Lepr Rev 1999; 70(4): 459-64.

11. Halder A, Misha RN, Halder S, Mahato L, Saha A K. Impact of modified leprosy elimination campaign in a MDT pilot project district of India. Indian J Public Health 2001; 45(3): 88-92. 
12. WHO. World Health Organization Report on the $5^{\text {th }}$ Meeting of the WHO Technical Advisory Group on Elimination of Leprosy; 2003.

13. WHO. World Health Organization. Technical Report Series. WHO Expert Committee on Leprosy. Geneva. 1998; 874: 1-43.

14. Rosner B. Fundamentals of Biostatistics ( $5^{\text {th }}$ Edition). New York: Duxbury Press; 2000.

15. Szklo M, Nieto J. Epidemiology: Beyond the Basics. Gaithersburg: Aspen Publishers, Inc; 2000.

16. Fleiss JL. Statistical Methods for Rates and Proportions. Wiley Series in Probability and Mathematical Statistics. 2 ed. USA; 1981.

17. Breslow NE, Day NE. Statistical Methods in Cancer Research. Voll. IARC Scientific Publications 1980; 32: 142-146.

18. Kleinbaum DG, Kupper LL, Muller KE, Nizam A. Applied Regression Analysis and Other Multivariable Methods ( $3^{\text {th }}$ Ed). Duxbury Press; 1998.

19. Rothman K, Greenland S. Modern Epidemiology ( $2^{\text {nd }}$ Ed). Philadelphia: Lippincot Williams \& Wilkins; 1998.

20. Statistical Package for Social Sciences (SPSS). Version 11.0. [Computer program]. Chicago: SPSS Inc.; 2004.

21. STATS DIRECT.2004. www.statsdirect.com. Download in March, 15, 2004.

22. MS. Ministério da Saúde. Portaria 173/2000. Instrução Normativa sobre o controle da hanseníase; 2000.

23. WHO. World Health Organization. WHO action programme for the elimination of leprosy: efficacy of single dose multi drug therapy for the treatment of single lesion paucibacillary leprosy. Indian J Lepr 1997; 69: 12129.

24. Martelli CM, Stefani MM, Gomes MK, Rebello RF, Penini S, Narahashi K et al. Single lesion paucibacilary leprosy: baseline profile of the Brazilian Multicenter Cohort Study. Int J Lepr Other Mycobact Dis 2000; 68(3): 247-57.

25. Gupte MD. Field trials of a single dose of the combination rifampicin-ofloxacin-minocycline (ROM) for the treatment of paucibacilary leprosy. Lepr Rev 2000; 71: S77-80.

26. Ji B, Grosset J. Combination of rifapentine-moxifloxacinminocycline (PMM) for the treatment of leprosy. Leprosy Review. 2000; 71: S81-7.

27. Revankar CR, Bulchand HO, Pai VV, Guanapati R. Singledose ROM treatment for multilesion paucibacilary leprosy-further observation. Int J Lepr Other Mycobact Dis 2002; 70(1): 37-8.
28. Katoch K, Natrajan M, Yavan VS, Bhata AS. Response of Leprosy patients with Single Lesions to MDT. Acta Leprológica 1995; 9(3): 133-137.

29. Borges E, Gallo MEN, Alvin MFS, Bittencourt E. Determinação do grau de incapacidade em hansenianos não tratados. Cad Saúde Pública 1987; 3(3): 266-271.

30. Claro LBL. Hanseníase: Representações sobre a Doença. Rio de Janeiro: Editora Fiocruz; 1995.

31. Oliveira MH, Romanelli G. Os efeitos da hanseníase em homens e mulheres: um estudo de gênero. Cad Saúde Pública 1998; 14(1): 51-60.

32. Moreira TMA, Varkevisser CM. Gender, leprosy and leprosy control: case study in Rio de Janeiro State, Brazil. KIT Publishers (Royal Tropical Institute). Amsterdam. ISBN: 9068327151; 2001.

33. Ponnighaus JM, Fine PE, Gruer PJ, Maine N. The anatomical distribution of the single leprosy lesions in a African population, and its implications for the pathogenesis of leprosy. Lepr Rev. 1990; 61(3): 242-50.

34. Jopling WH. Handbook of Leprosy ( $3^{\text {rd }}$ Ed). London: Willian Heinemann Medical Books LTD; 1984.

35. Latapi F, Saúl A, Rodriguez O, Malacara M, Browne G. Leprosy. Proceedings of the XI International Leprosy Congress, Mexico City, November 13-18, 1978. Excerpta Medica, Amsterdam - Oxford - Princeton; 1980. p. 70.

36. Matos HJ, Duppre N, Alvim MFS, Vieira LMM, Sarno EM, Struchiner CJ. Epidemiologia da hanseníase em coorte de contatos intradomiciliares no Rio de Janeiro (1987-1991). Cad Saúde Pública 1999; 15(3): 533-42.

37. Van Beers SM, Hatta M, Klatser PR. Patient Contact is the major Determinant in Incident Leprosy: Implications for Future Control. Int J Lepr Other Mycobact Dis 1999; 67(2): 119-128.

38. Ignotti E. O paradoxo dos indicadores de monitoramento da eliminação da hanseníase. [tese de doutorado]. Rio de Janeiro: Escola Nacional de Saúde Pública, Fundação Oswaldo Cruz; 2004.

39. MS. Ministério da Saúde, Fundação Nacional de Saúde. Coordenação Nacional de Dermatologia Sanitária. Guia de Controle da Hanseníase (2 ${ }^{\mathrm{a}}$ ed). Brasília; 1994.

40. PAHO. Pan-American Health Organization. World Health Organization. Leprosy Elimination Monitoring (LEM). Manual dos monitores do LEM multicêntrico Brasil 2003. www.opas.org.br/hanseniase.

41. PAHO. Pan-American Health Organization. World Health Organization. Final Report of Leprosy Elimination Monitoring (LEM) Brasil 2003. www.who.int/lep. Consulted in May, 20, 2004.

Recebido em: 08/11/06 Versão final reapresentada em: 30/05/07 Aprovado em: 11/06/07 